\title{
HYDROLOGICAL ANALYSIS OF THE WATERSHED OF AN NAJAF PROVINCE BY GIS
}

\author{
Ali H. Al Rammahi ${ }^{1}$, Emad A. Al Helaly ${ }^{2}$, AbudAlla H. Al Khafagi ${ }^{3}$ and Mohammed Q. \\ Al Bedieri ${ }^{3}$ \\ ${ }^{1}$ Faculty of Engineering, University of Kufa. Email: alih.jabir@uokufa.edu.iq \\ ${ }^{2}$ Faculty of Engineering, University of Kufa. Email: imada.alhilali@uokufa.edu.iq \\ ${ }^{3}$ Engineering, University of Kufa. Email: eng.abdulla@gmail.com \\ ${ }^{4}$ Engineering, University of Kufa. Email: mohammed1994315@gmail.com
}

\section{HTTP://DX.DOI.ORG/10.30572/2018/KJE/120203}

\begin{abstract}
The analysis of the watershed gives the surface area of land that rain streamed arrived in the river. The modern method to analyze the catchment is the ArcGIS program based on the Digital Elevation Model (DEM). The study area is An Najaf province, which area equaled about 27675 square kilometers. The HECGeoHMS (Hydrologic Engineering Center's Hydrologic Modeling System) is the link program on the ArcMap software that abled by serious steps to analyze the specific watershed. The auto analysis of the watershed area gives four basins for each outlet points located on the distributary Euphrates river. These four basins consisted of multi subbasins and streams of rain flow. Basin 4 has the most significant volume, about $11.4 \%$ of the total case area of the basin, and the average slope is $3.2 \%$. According to the amount of accumulative rainwater, basin 4 is essential when any obstruction is constructed at the end of the outlet point in the stream. This location of the construct is used to prevent the sediment in the Euphrates river and to avoid surface soil degradation. The arrangement of importance basin based on the advantage of water using to give maximum discharge and low evaporation is basin four at the first, basin two at the second.
\end{abstract}

\section{KEYWORDS}

DEM, watershed, HECGeoHMS, Najaf 


\section{INTRODUCTION}

The watershed analysis model is the first step to study the hydrologic cycles and the possibility of water management. The formation of channels, location of drainage, channel slope, channel length, and other physical information was obtained by the watershed model (Garbrecht et al 2000 and Panagos et al 2015). Digital Elevation Model (DEM) is the best-computerized data to analyze the watershed of a specific region (Douglas 1986). DEM is used to obtain information about the morphology of the earth's surface (Elassal and Vincent 1983). Analysis of DEM gives the map of stream channel as automatically and dividing the network of the catchment (Band 1986). The information of DEM was increased based on the digital topography, especially over the last two decades (Jenson et al 1988, Mark 1984, Moore et al 1991 and Martz et al 1992). The analysis of topographic watershed based on the DEM is faster and reproducible measurements which comparison with traditional manual methods (Tribe 1991). Geographic Information System (GIS) is readily imported and analyzed the digital data of DEMs.The technological of GIS and digital data of DEM was used the application of hydrologic, water resources, and environmental investigations (Moore et al 1991).

The aim of this study has analyzed the watershed of An Najaf province based on the DEMs images with resolution $30 \mathrm{~m} \times 30 \mathrm{~m}$ and ArcGIS software. The research was conducted to request from the Directorate of Agriculture in Najaf province to improve the agricultural situation and the rainfall management, especially the vast bare land of the study region.

\subsection{STUDY AREA}

The study area is Najaf Province, one of the provinces in the Middle Euphrates in Iraq located southwest of capital Baghdad about $161 \mathrm{~km}$ away. The location of longitude and latitude, as shown in Fig. 1. At the southeast of this province, the valley was located, and most areas of the province are bare. Euphrates River and its distributary channels are passed through the study area, which represented as a polygon in Fig. 2 by using ArcGIS software. The case study area was occupied about 27675 square kilometers.

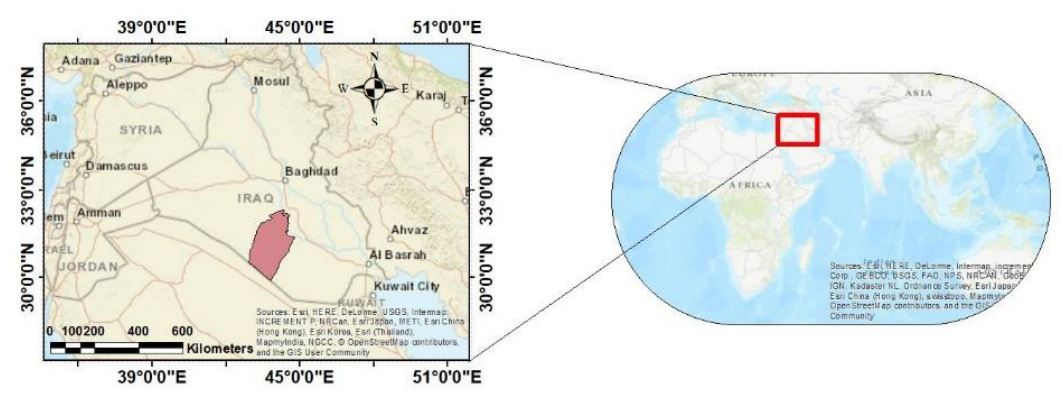

Fig. 1 The location of Najaf province. 


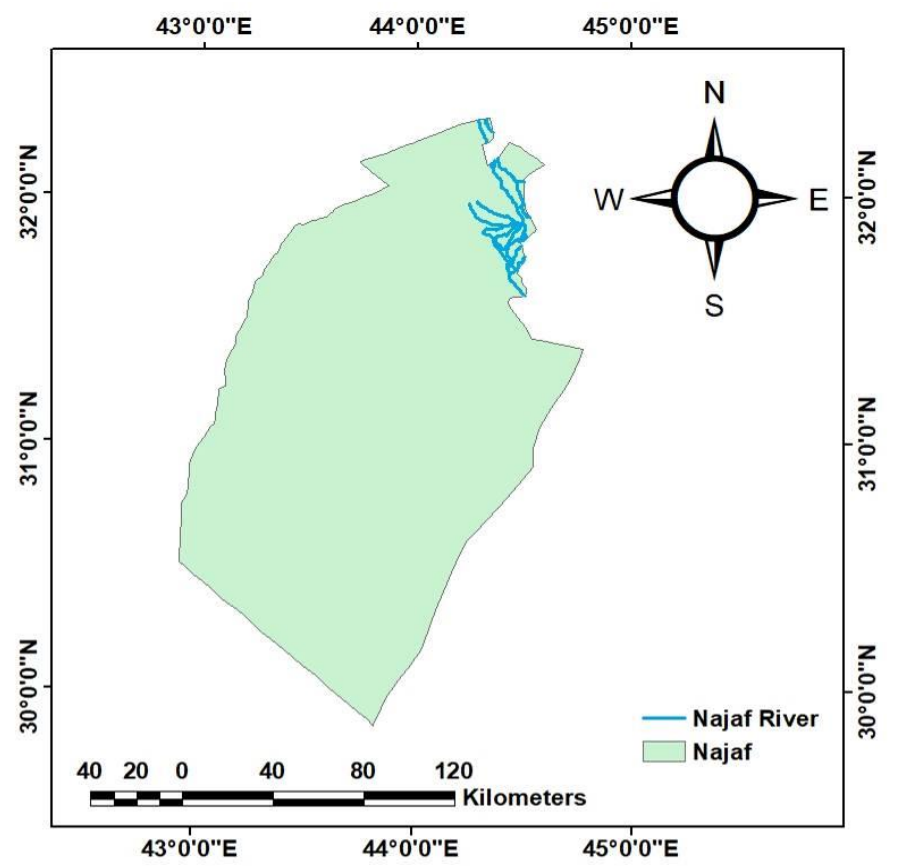

Fig. 2 The polygon of Najaf province and Euphrates river.

\section{MATERIALS AND METHODS}

The DEMs images were downloaded from Shuttle Radar Topography Mission (SRTM) 1 ArcSecond Global of USGS (United States Geological Survey) in September 2014. The number of these raw images equaled eight that processed by using the series steps of ArcMap software, as shown in Fig. 3.

Each area of the DEM classification can be computed by knowing the number of cells and dimensions of its $(30 \mathrm{~m} \times 30 \mathrm{~m})$, as shown in Table 1 . The number of cells that ranged between -1 to 0 was minimal, so the ranges of DEM for the present watershed can be taken from 0 to $450 \mathrm{~m}$. The highest elevations were recorded in the south-west, and the deepest elevations were observed at the province center. The ranges of elevation from $300 \mathrm{~m}$ to $450 \mathrm{~m}$ had a large percentage of about $42 \%$ of the total case study area located in the south-west region.

The extracted DEM map is the dataset of the watershed analysis of the case study. HECGeoHMS (Hydrologic Engineering Center's Hydrologic Modeling System) is the link program on the ArcMap software that abled by series steps to analyze the specific watershed. The series summary steps are computed the flow direction, flow accumulation, and stream segment then preparing the hydrological model based on raw DEM and polygon of river stream in the area.

The outlet point must be selected to specify the area poured into it. The outlet of the case study selected at the distributary of the Euphrates river that passed through this watershed and another 
reason for outlet points selectively is the vast area of bare land located near the distributary stream. There are four outlet points selected on the distributary river, as shown in Fig. 4. For each outlet point, the basin areas of the watershed were auto estimated by the HECGeoHMS program.

Table 1. The ranges of each classification of DEM .

\begin{tabular}{ccc}
\hline Range & total area $\mathbf{k m}^{\mathbf{2}}$ & Area \% \\
\hline$-1-0$ & 0.0045 & $1.62601 \mathrm{E}-05$ \\
$0-50$ & 2256.0129 & 8.151782416 \\
$50-100$ & 2150.7957 & 7.771594997 \\
$100-150$ & 2294.532 & 8.290965716 \\
$150-200$ & 2455.101 & 8.871159008 \\
$200-250$ & 3113.8758 & 11.25154825 \\
$250-300$ & 3875.5548 & 14.00376721 \\
$300-350$ & 5903.874 & 21.33281076 \\
$350-450$ & 5625.3366 & 20.32635539 \\
\hline
\end{tabular}

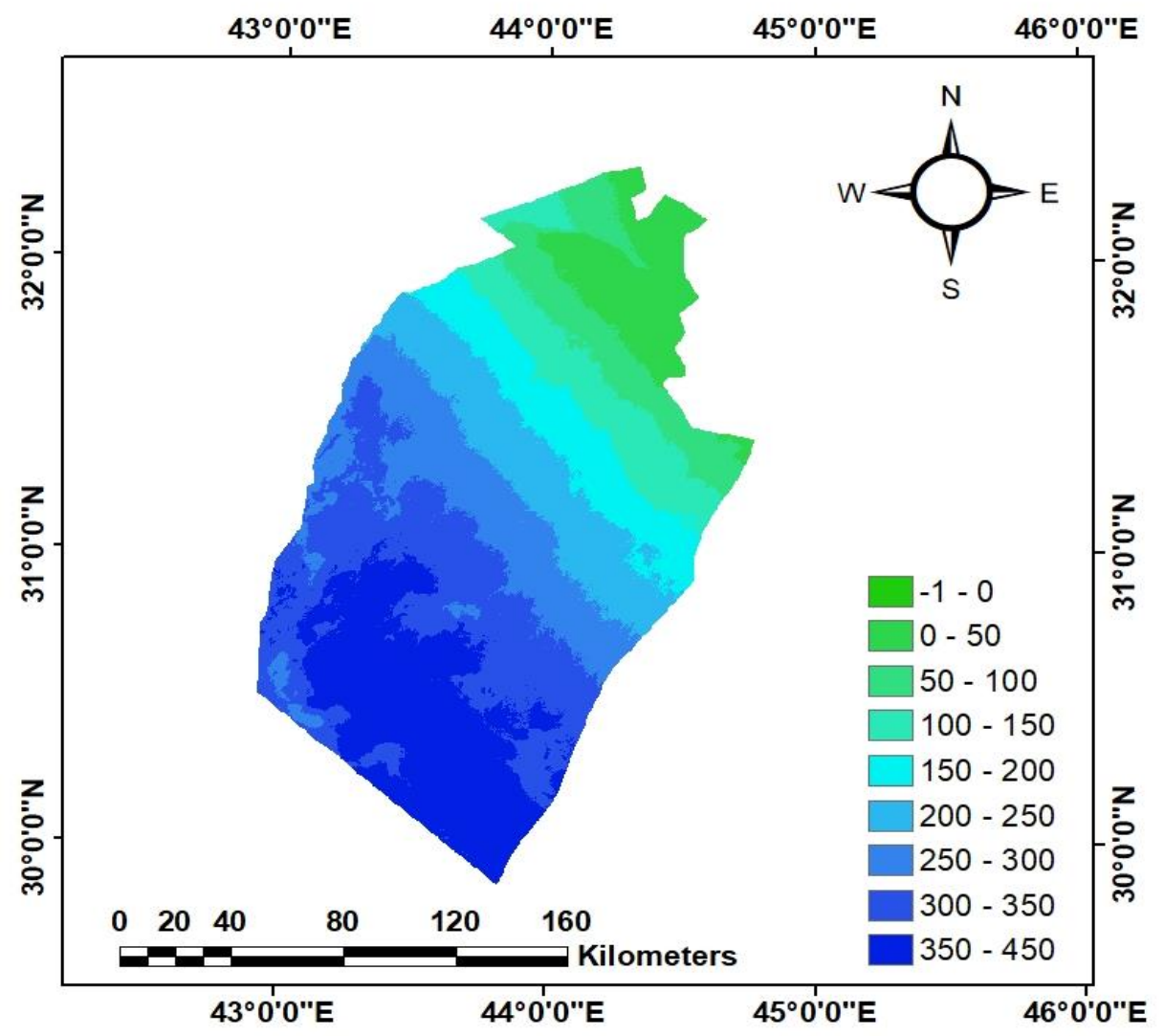

Fig. 3. The Digital Elevation Model (DEM) of An Najaf province. 


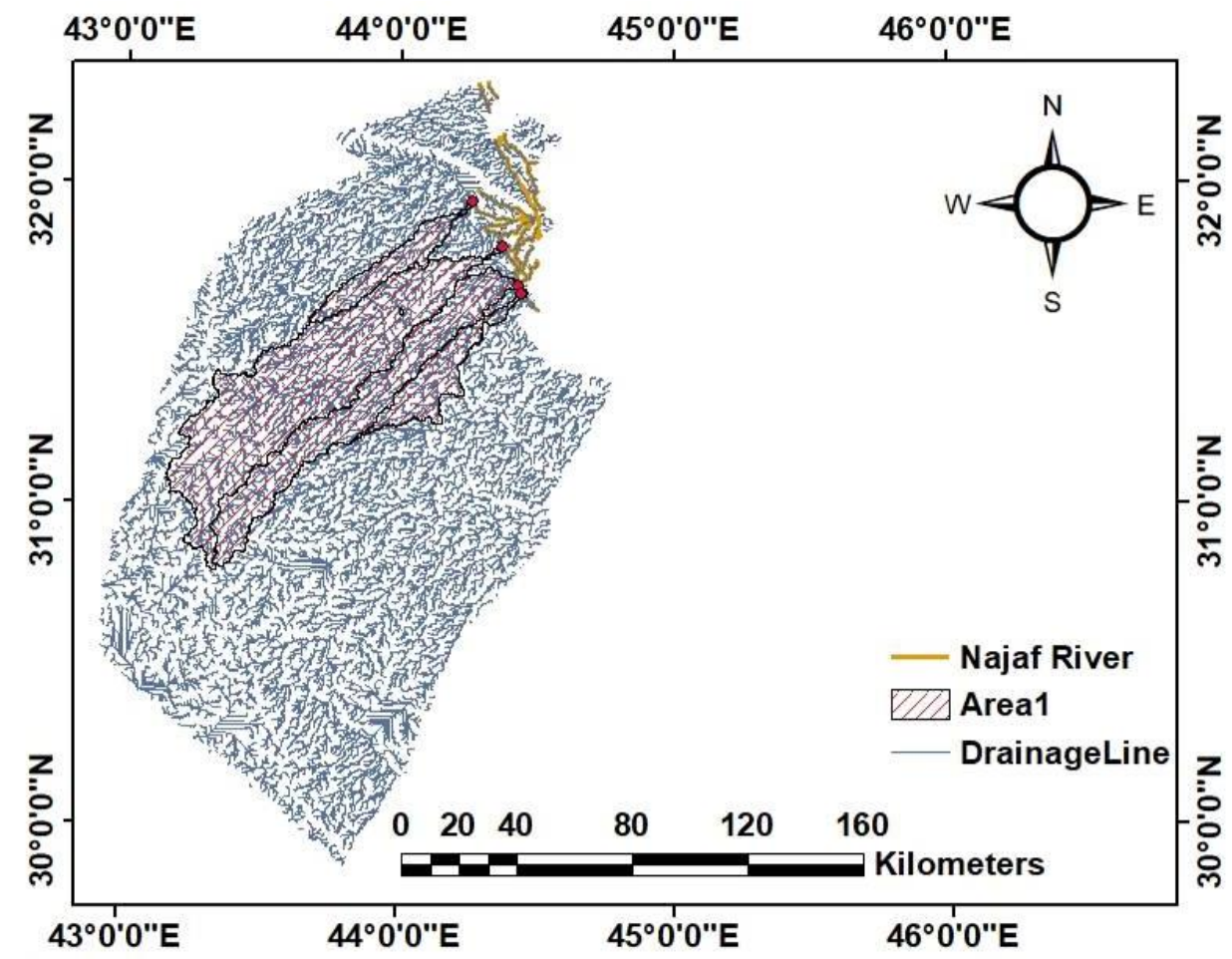

Fig. 4. The outlet points and basins of the case study region.

\section{RESULTS AND DISCUSSION}

The four basins and their locations appeared as different colors in Fig. 5; these basins represented four outlet points and they were located on streams of Euphrates river branches. Basin 1 was contained from six sub-basins which showed in Fig.s 6 and 7. The area, length, and slope of sub-basins as shown in Table 2, the average slope of basin 1 is $2.8 \%$ while the area of this basin is 440.2 square kilometers, about $1.6 \%$ of the total area of An Najaf.

Basin 2 consisted of six sub-basins of the rill steam, which arrived at the Euphrates river, as shown in Figs. 6 and 7. The total area of this basin was 1584.4 square kilometers, about 5.7\% of the total area of Najaf. The average slope of basin 2 is $2.7 \%$; all details of this basin shown in Table 3.

The auto division of basin 3 depended on the terrains is contained from four sub-basin and streams which exposed in Figs. 8 and 9. Table 4 showed all the details of basin 3. The average slope of this basin is $2.4 \%$, while the total area of the basin is 557.3 square kilometers, about $2 \%$ of the total area of the case study.

The most significant basin area is basin four that involved five sub-basins, as shown in Fig. 10 and 11 . The area of the basin is 3165.6 square kilometers, about $11.4 \%$ of the total area while 
the average slope of this basin is $3.2 \%$. This basin has a maximum slope compared with other basins. All details of the basin exposed in Table 5.
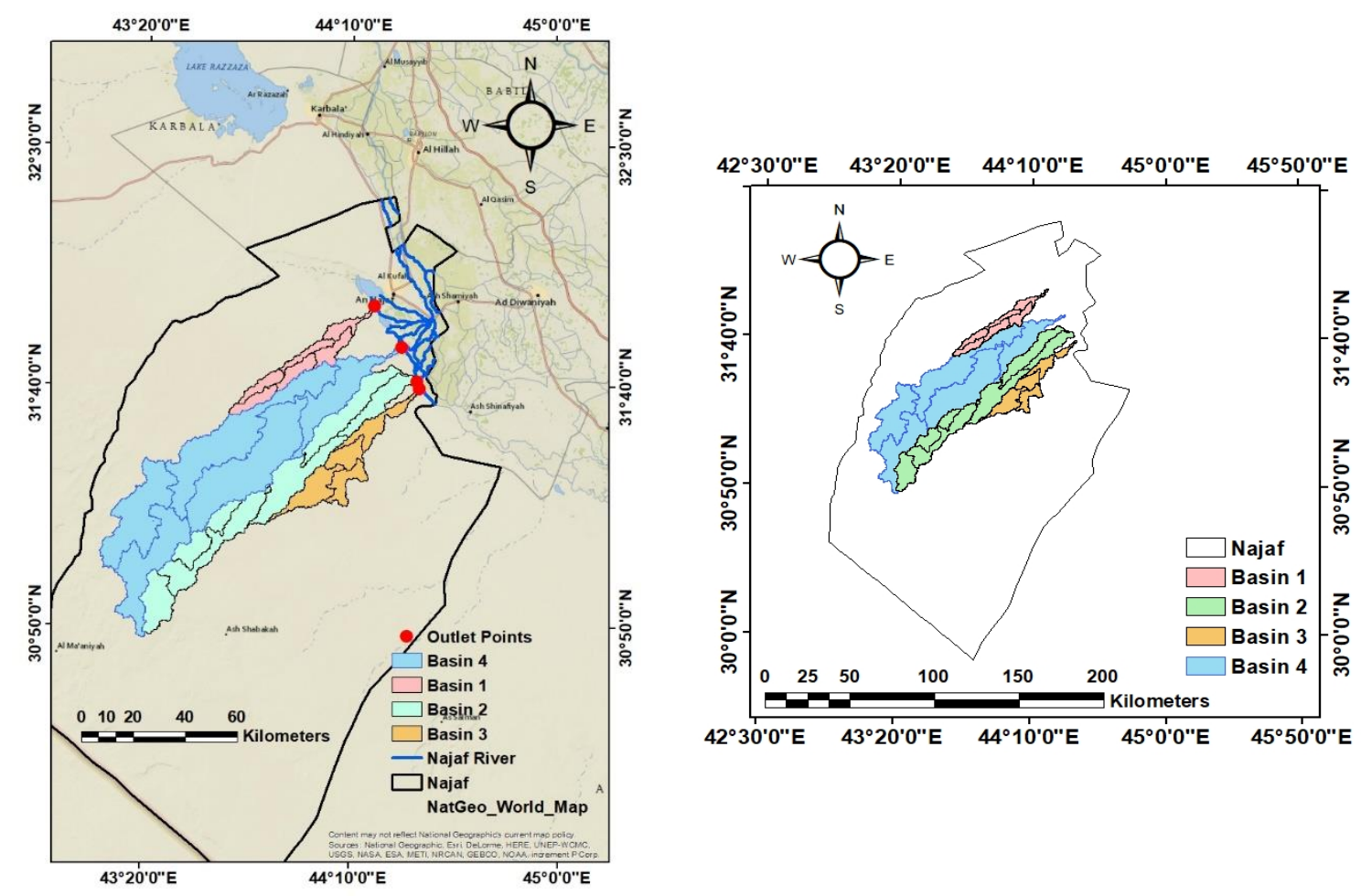

Fig. 5. The four basins and its locations.

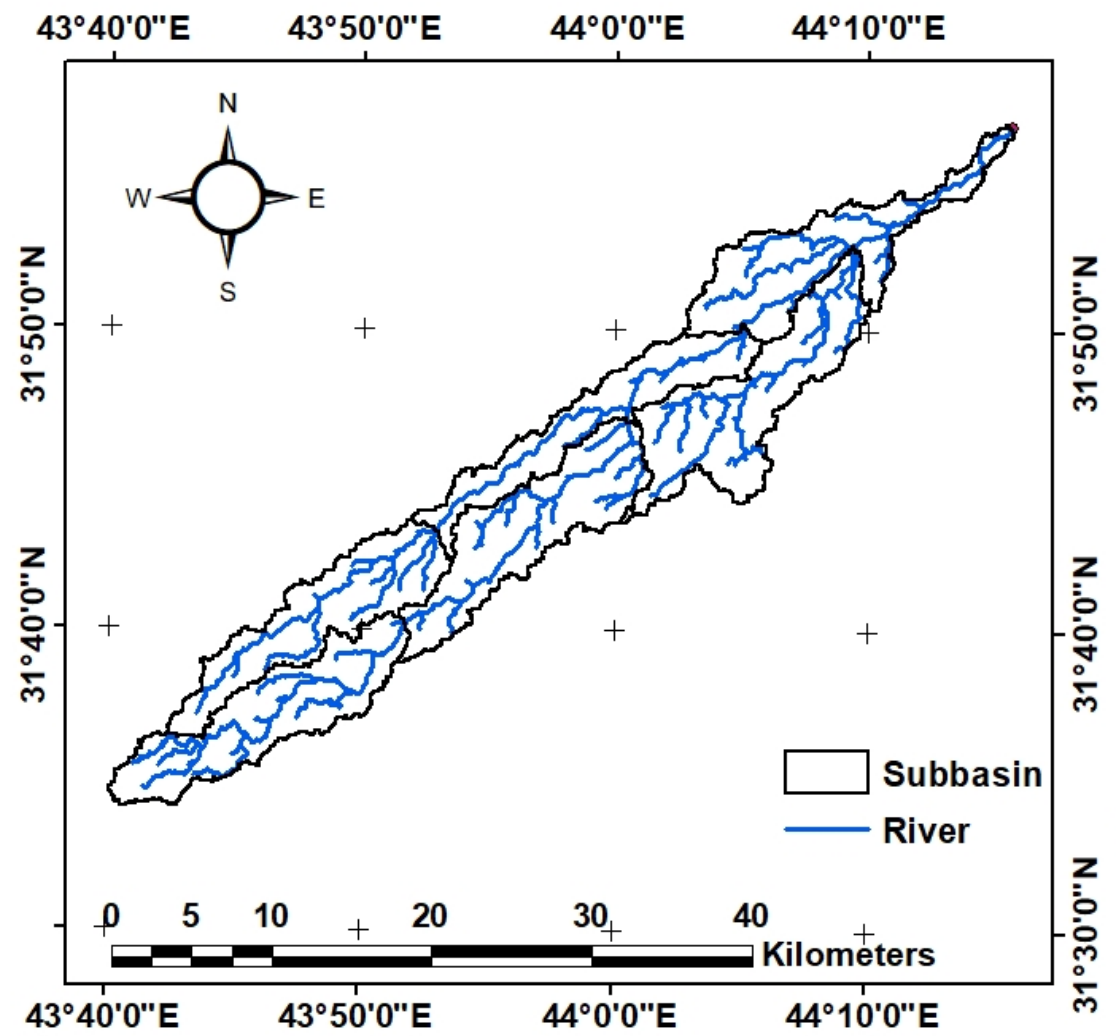

Fig. 6. The distributary's streams of the basin1 . 


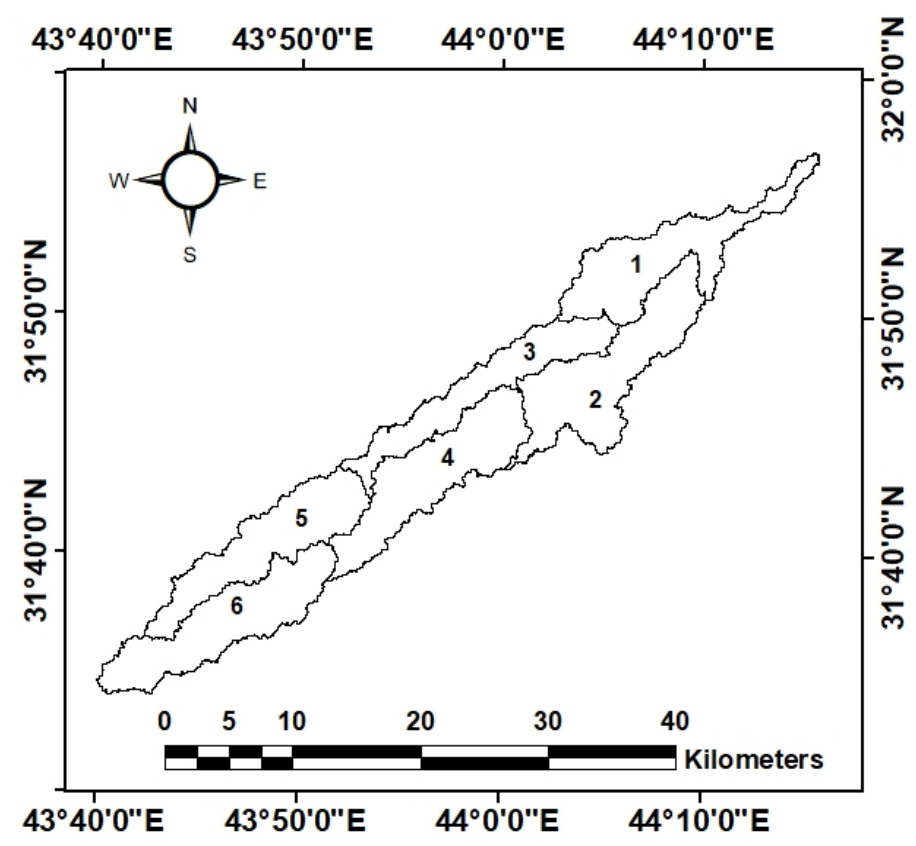

Fig. 7. The sub-basins of basin 1 .

Table 2. The details of sub-basins of basin 1 .

\begin{tabular}{cccc}
\hline Basin No. & Area km2 & Basin length km & Slope basin\% \\
\hline 1 & 72.11 & 103.68 & 2.84 \\
2 & 85.58 & 96.78 & 2.80 \\
3 & 59.49 & 98.34 & 2.91 \\
4 & 77.31 & 86.16 & 2.65 \\
5 & 69.76 & 83.58 & 2.70 \\
6 & 75.96 & 84.18 & 2.95 \\
\hline
\end{tabular}

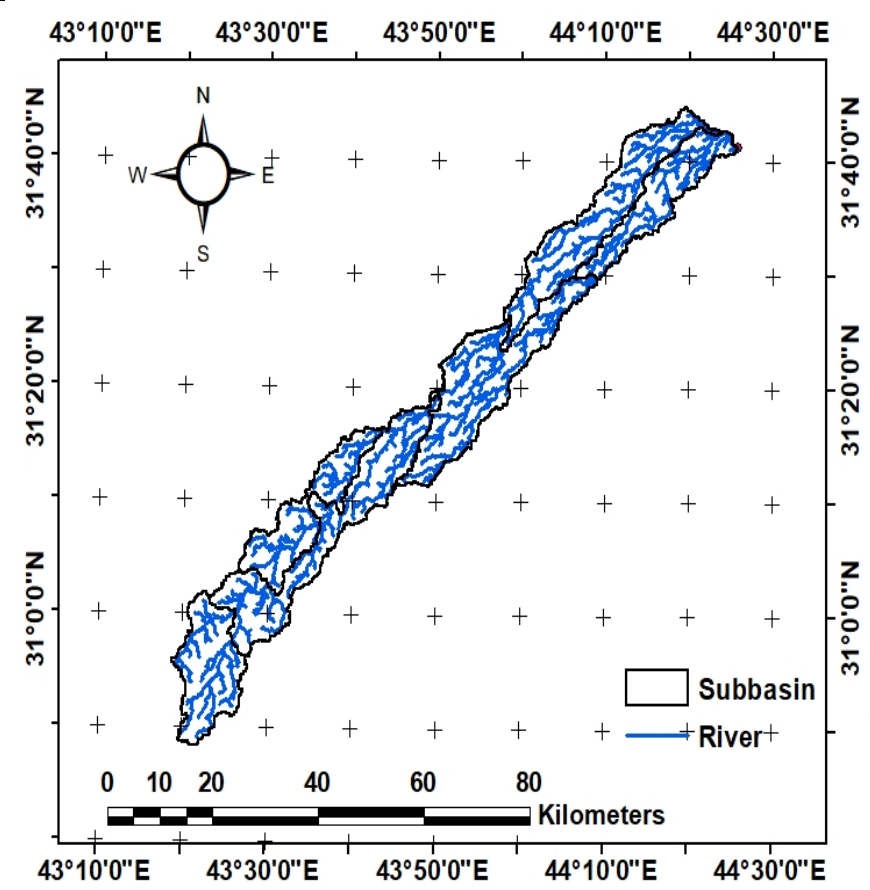

Fig. 6. The distributary's streams of the basin 2. 
Table 3. The details of sub-basins of basin 2 .

\begin{tabular}{cccc}
\hline Basin No. & Area km & Basin length km & Basin slope \% \\
\hline 1 & 187.03 & 150.54 & 2.46 \\
2 & 304.57 & 224.88 & 2.41 \\
3 & 338.60 & 229.68 & 2.62 \\
4 & 346.33 & 275.22 & 3.01 \\
5 & 199.13 & 175.08 & 3.27 \\
6 & 208.76 & 121.20 & 2.67
\end{tabular}

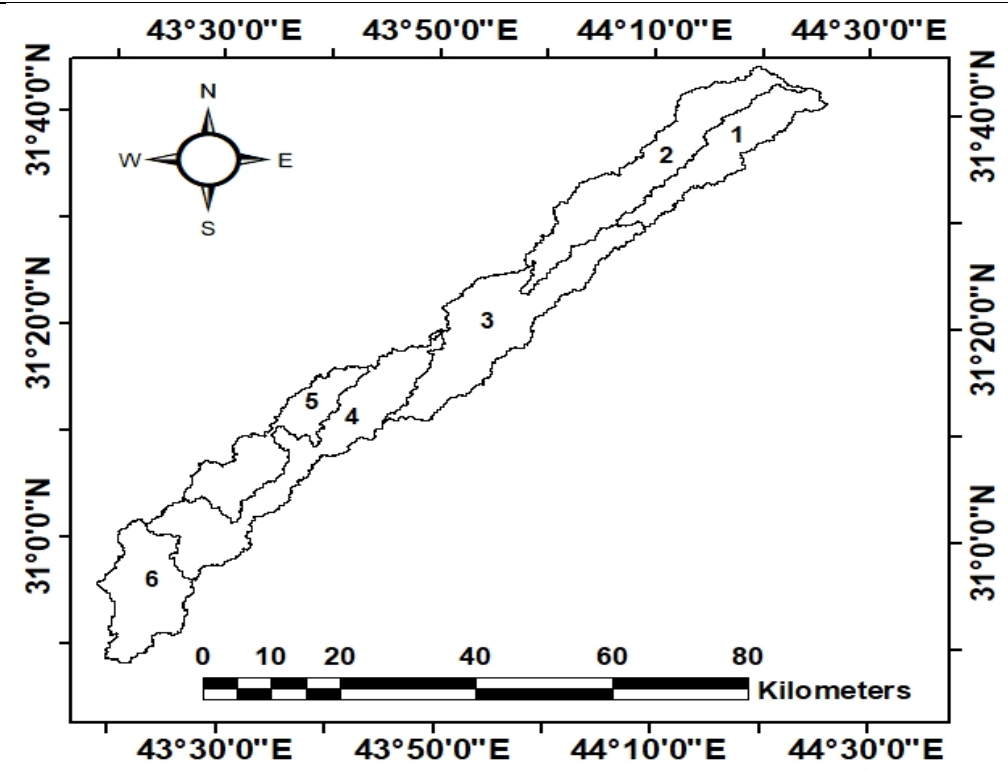

Fig. 7. The sub-basins of basin 2 .

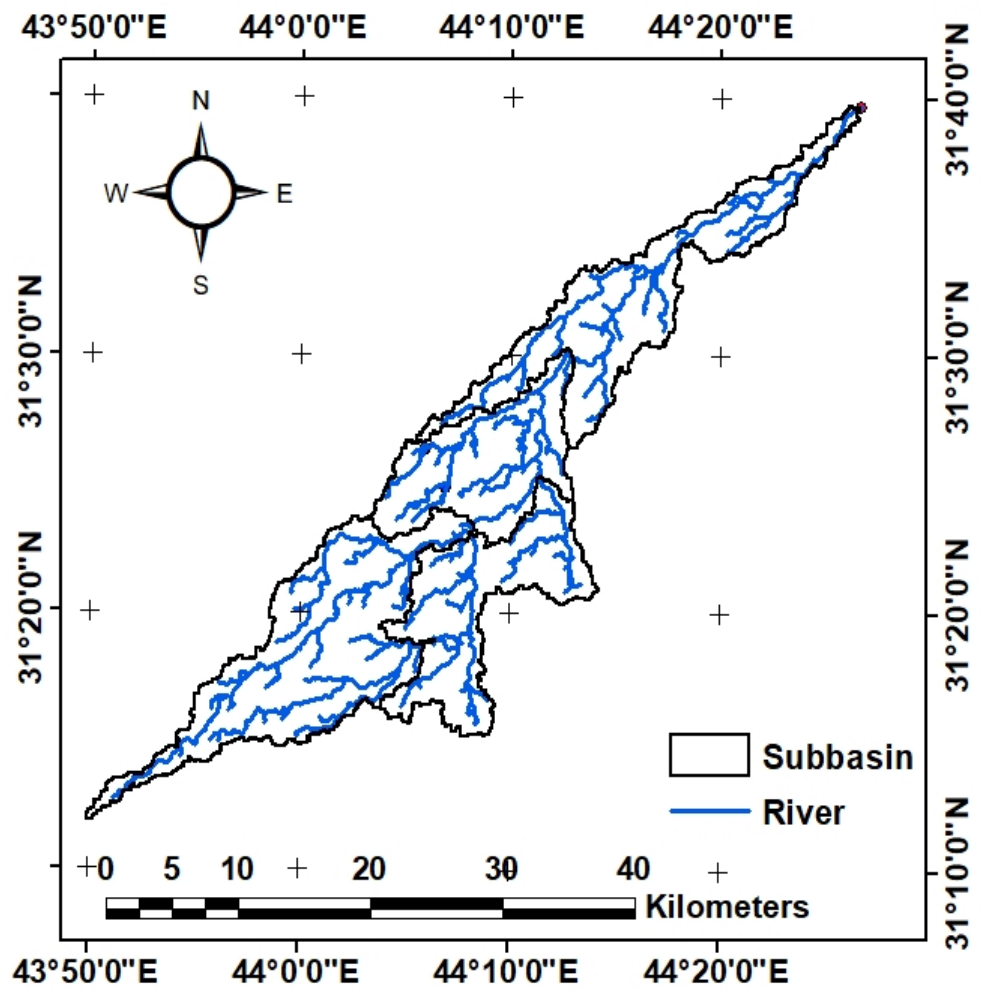

Fig. 8. The distributary's streams of the basin 3 . 


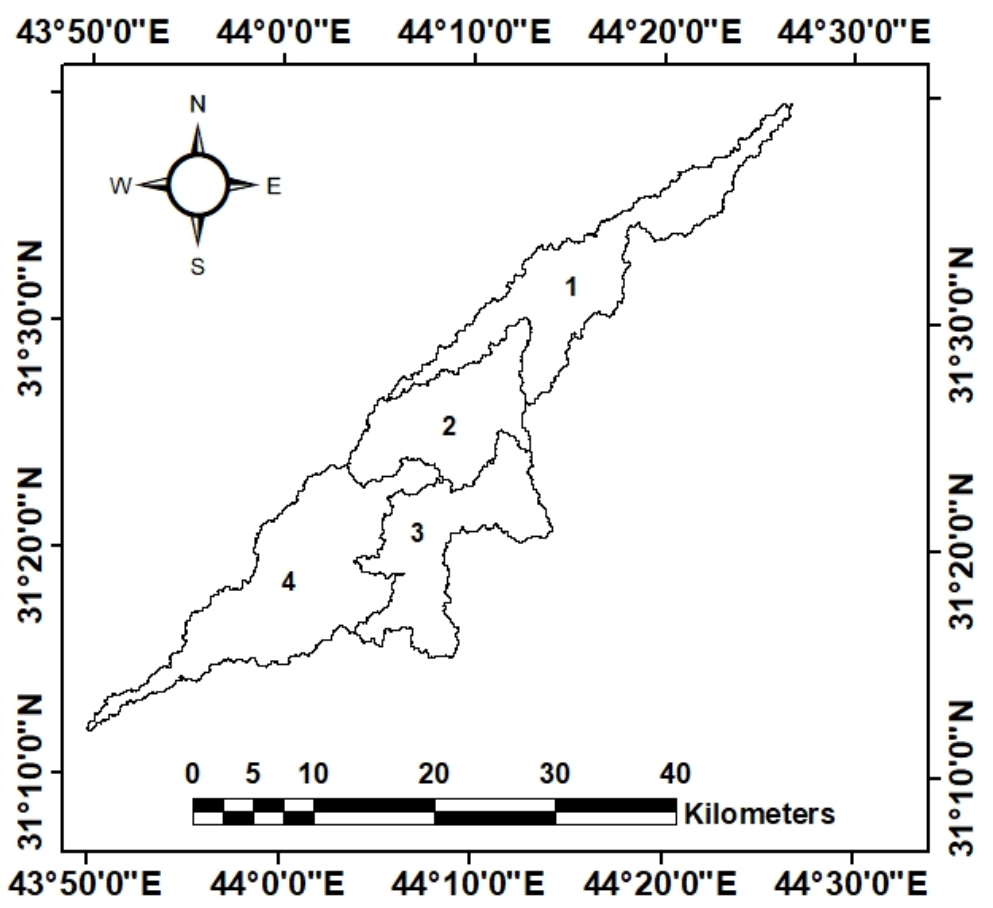

Fig. 9 The sub-basins of basin 3.

Table 4. The details of sub-basins of basin 3 .

\begin{tabular}{cccc}
\hline Basin No. & Area km2 & Basin length km & Basin slope \\
\hline 1 & 145.48 & 179.88 & 2.37 \\
2 & 107.29 & 89.64 & 2.38 \\
3 & 117.39 & 124.08 & 2.39 \\
4 & 187.12 & 158.04 & 2.46 \\
\hline
\end{tabular}

Table 5. The details of sub-basins of basin 4 .

\begin{tabular}{cccc}
\hline Basin No. & Area km2 & Basin length km & Slope basin\% \\
\hline 1 & 407.91 & 286.20 & 2.58 \\
2 & 813.45 & 442.80 & 3.29 \\
3 & 868.83 & 330.54 & 3.11 \\
4 & 556.25 & 287.88 & 3.61 \\
5 & 519.13 & 314.04 & 3.38 \\
\hline
\end{tabular}




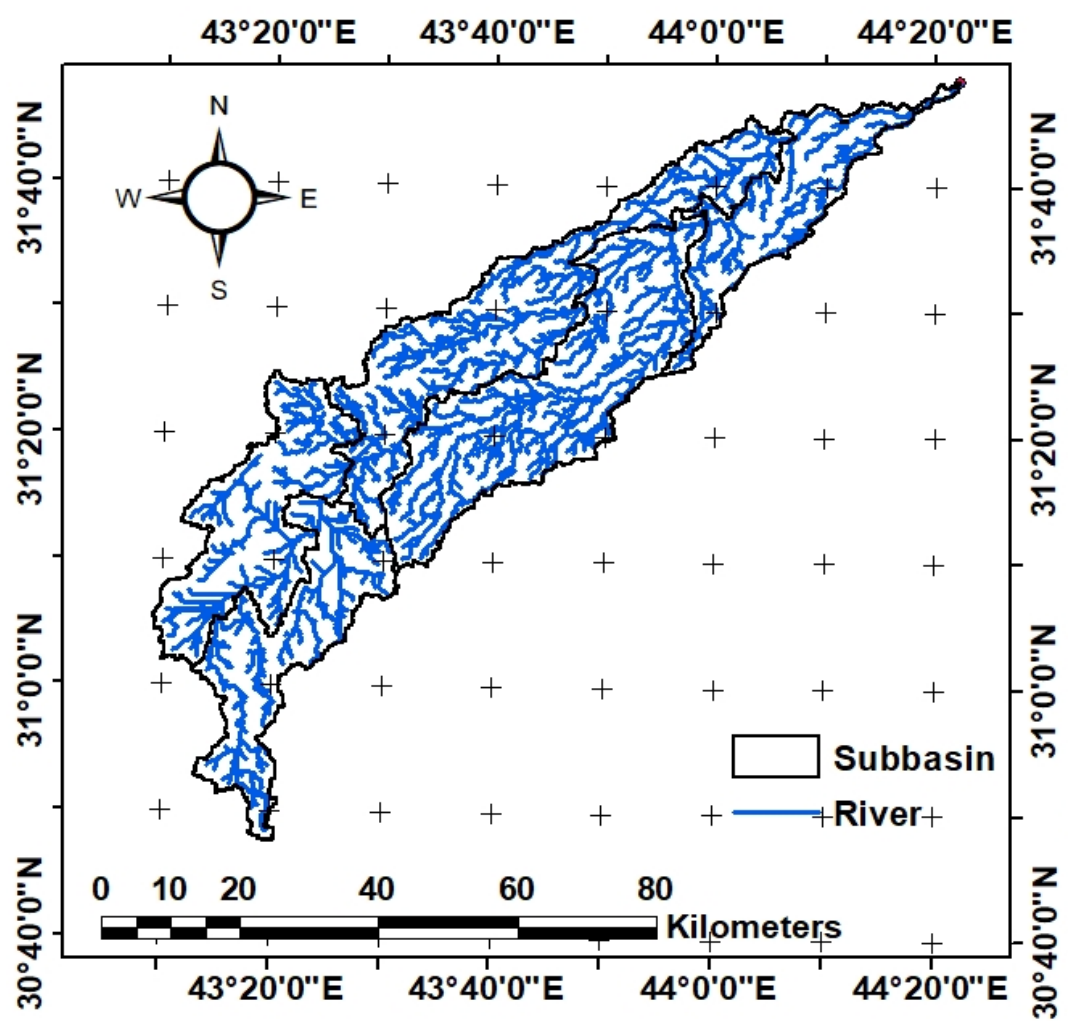

Fig. 10. The distributary's streams of the basin 4 .

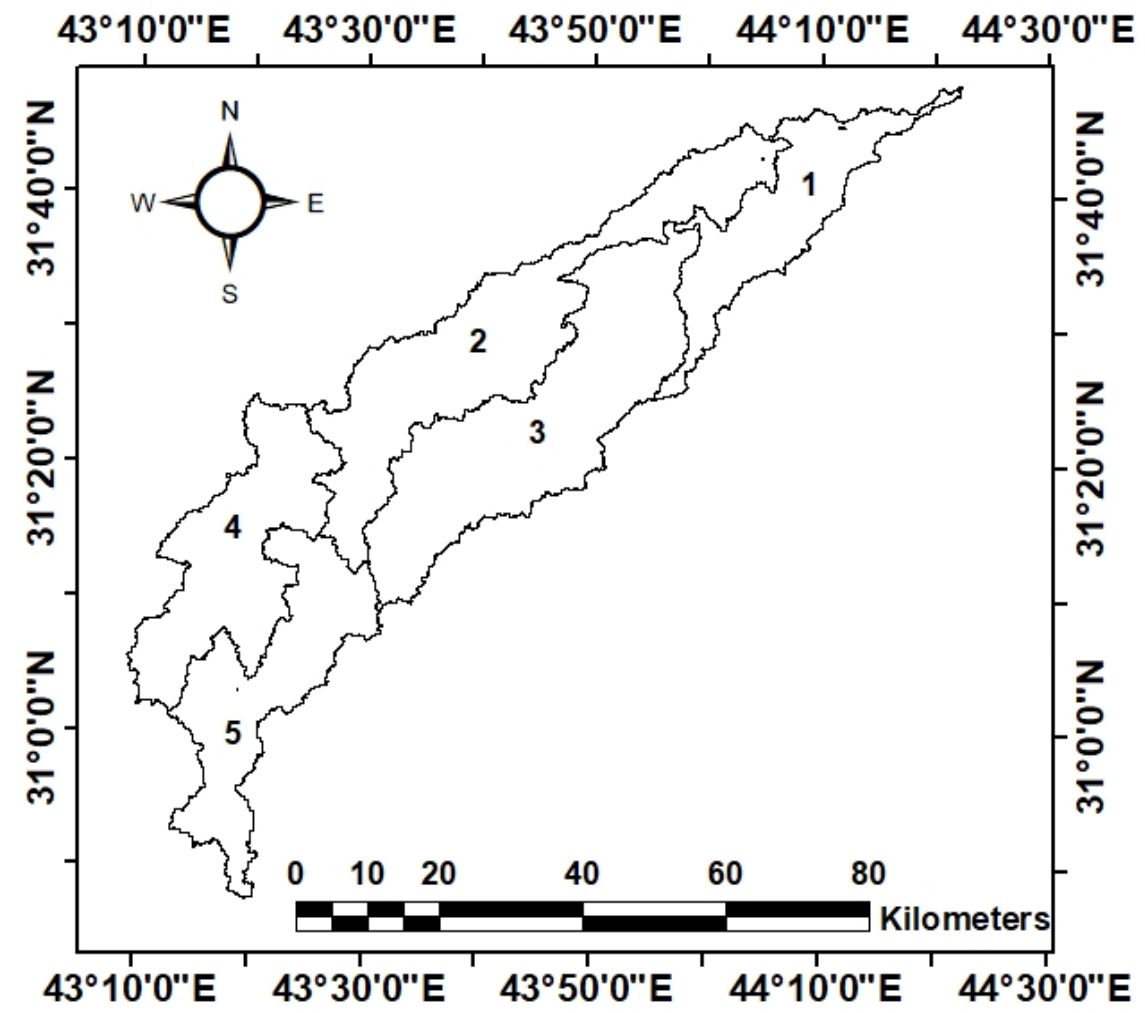

Fig. 11. The sub-basins of basin 4 . 


\section{CONCLUSION}

The catchment analysis based on DEM is the best method to find the area of basin and rill streams. The DEM of a Najaf province arranged from 0 to $450 \mathrm{~m}$ above the sea level, $42 \%$ of the total area located at the southwest of the case study had elevation from 300 to $450 \mathrm{~m}$. The results displayed four basins that stream in the distributary Euphrates river. These basins consisted of multi sub-basins, basin 4 has the most significant area, about $11.4 \%$ of the total area of the basin, and the average slope is $3.2 \%$. This reason basin 4 is the critical basin to accumulate the water due to rain by using any construct at the end of the stream. This location of the construct is used to prevent the sediment in the Euphrates river and to avoid surface soil degradation. The arrangement of importance basin based on the advantage of water using to give maximum discharge and low evaporation is basin four at the first, basin two at the second.

\section{REFERENCES}

Band, L. E. (1986) 'Topographic partition of watersheds with digital elevation models, Water resources research. Wiley Online Library, 22(1), pp. 15-24.

Douglas, D. H. (1986) 'Experiments to locate ridges and channels to create a new type of digital elevation model', Cartographica: The International Journal for Geographic Information and Geovisualization. University of Toronto Press, 23(4), pp. 29-61.

Elassal, A. A. and Caruso, V. M. (1983) Digital elevation models. US Department of the Interior, Geological Survey.

Garbrecht, J. and Martz, L. W. (2000) 'Digital elevation model issues in water resources modeling', Hydrologic and hydraulic modeling support with geographic information systems. Redlands, CA: ESRI Press, pp. 1-28.

Jenson, S. K. and Domingue, J. O. (1988) 'Extracting topographic structure from digital elevation data for geographic information system analysis', Photogrammetric engineering and remote sensing. Citeseer, 54(11), pp. 1593-1600.

Mark, D. M. (1984) 'Part 4: mathematical, algorithmic and data structure issues: automated detection of drainage networks from digital elevation models', Cartographica: The International Journal for Geographic Information and Geovisualization. University of Toronto Press, 21(2-3), pp. 168-178. 
Martz, L. W. and Garbrecht, J. (1992) 'Numerical definition of drainage network and subcatchment areas from digital elevation models', Computers \& Geosciences. Elsevier, 18(6), pp. 747-761.

Moore, I. D., Grayson, R. B. and Ladson, A. R. (1991) 'Digital terrain modelling: a review of hydrological, geomorphological, and biological applications', Hydrological processes. Wiley Online Library, 5(1), pp. 3-30.

Panagos, P., Borrelli, P. and Meusburger, K. (2015) 'A new European slope length and steepness factor (LS-Factor) for modeling soil erosion by water', Geosciences. Multidisciplinary Digital Publishing Institute, 5(2), pp. 117-126.

Tribe, A. (1991) ‘Automated recognition of valley heads from digital elevation models', Earth surface processes and landforms. Wiley Online Library, 16(1), pp. 33-49. 